Wilfrid Laurier University

Scholars Commons @ Laurier

2010

\title{
The Effect of Natural Dissolved Organic Carbon on the Acute Toxicity of Copper to Larval Freshwater Mussels (Glochidia)
}

\author{
Patricia L. Gillis \\ University of Guelph \\ James C. McGeer \\ Wilfrid Laurier University, jmcgeer@wlu.ca \\ Gerald L. Mackie \\ University of Guelph \\ Michael P. Wilkie \\ Wilfrid Laurier University, mwilkie@wlu.ca \\ Josef D. Ackerman \\ University of Guelph
}

Follow this and additional works at: https://scholars.wlu.ca/biol_faculty

\section{Recommended Citation}

Gillis, Patricia L.; McGeer, James C.; Mackie, Gerald L.; Wilkie, Michael P.; and Ackerman, Josef D., "The Effect of Natural Dissolved Organic Carbon on the Acute Toxicity of Copper to Larval Freshwater Mussels (Glochidia)" (2010). Biology Faculty Publications. 33.

https://scholars.wlu.ca/biol_faculty/33

This Article is brought to you for free and open access by the Biology at Scholars Commons @ Laurier. It has been accepted for inclusion in Biology Faculty Publications by an authorized administrator of Scholars Commons @ Laurier. For more information, please contact scholarscommons@wlu.ca. 


\title{
THE EFFECT OF NATURAL DISSOLVED ORGANIC CARBON ON THE ACUTE TOXICITY OF COPPER TO LARVAL FRESHWATER MUSSELS (GLOCHIDIA)
}

\author{
Patricia L. Gillis, ${ }^{*} \dagger \ddagger$ James C. McGeer, $\S$ Gerald L. Mackie, $\dagger$ Michael P. Wilkie, $\S$ and Josef D. Ackerman $\dagger$ \\ $\dagger$ Department of Integrative Biology, University of Guelph, Guelph, Ontario N1G 2W1, Canada \\ $\ddagger$ Aquatic Ecosystem Protection Research Division, Environment Canada, Burlington, Ontario L7R 4A6, Canada \\ $\S$ Department of Biology, Wilfrid Laurier University, Waterloo, Ontario N2L 3C5, Canada
}

(Submitted 28 September 2009; Returned for Revision 23 December 2009; Accepted 9 June 2010)

\begin{abstract}
The present study examined the effect of dissolved organic carbon (DOC), both added and inherent, on Cu toxicity in glochidia, the larvae of freshwater mussels. Using incremental additions of natural DOC concentrate and reconstituted water, a series of acute copper toxicity tests were conducted. An increase in DOC from 0.7 to $4.4 \mathrm{mg} \mathrm{C} / \mathrm{L}$ resulted in a fourfold increase $(36150 \mu \mathrm{g} \mathrm{Cu} / \mathrm{L})$ in the $24 \mathrm{~h}$ median effective concentration (EC50) and a significant linear relationship $\left(r^{2} \quad 0.98, p \quad 0.0008\right)$ between the DOC concentration and the $\mathrm{Cu}$ EC50 of Lampsilis siliquoidea glochidia. The ameliorating effect of added DOC on Cu toxicity was confirmed using a second mussel species, the endangered (in Canada) Lampsilis fasciola. The effect of inherent (i.e., not added) DOC on Cu toxicity was also assessed in eight natural waters (DOC $515 \mathrm{mg} \mathrm{C/L}$ ). These experiments revealed a significant relationship between the EC50 and the concentration of inherent DOC $\left(r^{2} \quad 0.79, p \quad 0.0031\right)$ with EC50s ranging from 27 to $111 \mu \mathrm{g} \mathrm{Cu} / \mathrm{L}$. These laboratory tests have demonstrated that DOC provides glochidia with significant protection from acute $\mathrm{Cu}$ toxicity. The potential risk that $\mathrm{Cu}$ poses to mussel populations was assessed by comparing $\mathrm{Cu}$ and DOC concentrations from significant mussel habitats in Ontario to the EC50s. Although overall mean $\mathrm{Cu}$ concentration in the mussel's habitat was well below the acutely toxic level given the concentration of DOC, episodic $\mathrm{Cu}$ releases in low DOC waters may be a concern for the recovery of endangered freshwater mussels. The results are examined in the context of current $\mathrm{Cu}$ water quality regulations including the U.S. Environmental Protection Agency's (U.S. EPA) biotic ligand model. Environ. Toxicol. Chem. 2010;29:2519 2528. (C) 2010 SETAC
\end{abstract}

Keywords Copper toxicity Dissolved organic carbon $\quad$ Freshwater mussels $\quad$ Glochidia $\quad$ Biotic ligand model

\section{INTRODUCTION}

Freshwater mollusks are among the most endangered groups of organisms in North America, with nearly $70 \%$ of the species designated as either threatened, endangered, or in decline [1]. Their decline has been attributed to a number of factors, including habitat alteration, loss of fish hosts, invasive species, and exposure to environmental pollution [2 5]. Some studies $[2,6]$ have suggested that environmental contamination may contribute to recruitment or reproductive failure in freshwater mussels. As with most organisms, the early life stages of freshwater mussels are the most sensitive to environmental pollution. The larvae, called glochidia, are obligate parasites on fish. Most species of freshwater mussels release their glo chidia from the brooding chambers in the gills of the female into the water column, where on contact they will encyst upon a host. The amount of time that a given glochidium is in the water column and exposed to waterborne contaminants can vary significantly (seconds to weeks) depending on the specific reproductive strategies of the species (luring or broadcasting) and how long it takes to make contact with a host [7]. Although freshwater mussels are sensitive to a range of pollutants, they are particularly sensitive to $\mathrm{Cu}[6,811]$. In fact, concerns have been expressed that water quality guidelines for $\mathrm{Cu}$ do not adequately protect the early life stages of freshwater mussels $[12,13]$. It is important that toxicity data for this sensitive early

\footnotetext{
* To whom correspondence may be addressed (patty.gillis@ec.gc.ca).

Published online 9 July 2010 in Wiley Online Library (wileyonlinelibrary.com).
}

life stage be included when water quality regulations are developed, because contaminants that reduce glochidia success will put mussel populations at risk.

As with all metals, $\mathrm{Cu}$ bioavailability is controlled by the composition of the exposure water. Major ions, including $\mathrm{Ca}$, $\mathrm{Mg}$, and $\mathrm{Na}$, compete with metal ions at the site of uptake $[14,15]$. Similarly, the presence of ligands, such as dissolved organic carbon (DOC), can bind with the metal ion and reduce its bioavailability [16]. Copper bioavailability is strongly influ enced by DOC. Free $\mathrm{Cu}$ ions $\left(\mathrm{Cu}^{2+}\right)$, the most bioavailable and thus toxic $\mathrm{Cu}$ species in solution [17], form complexes with the negatively charged natural organic matter, reducing the amount of free $\mathrm{Cu}$ in solution and thereby reducing the bioavailability of $\mathrm{Cu}$ [18]. In fact, Mantoura et al. [19] reported that greater than $90 \%$ of $\mathrm{Cu}$ in freshwater was complexed by humic materials. The effect of copper DOC complexation on the bioavailability and toxicity of $\mathrm{Cu}$ has been demonstrated in a range of aquatic organisms, from cladocerans to fish [20 25], but until recently information on the effect of DOC on $\mathrm{Cu}$ toxicity in freshwater mussels was relatively scarce. Wang et al. [26] evaluated the effect of natural DOC on acute $\mathrm{Cu}$ toxicity in juvenile fresh water mussels. They observed a significant linear increase in the Cu EC50 (7 12 fold) when exposure solutions were augmented with up to $10 \mathrm{mg} / \mathrm{L}$ of natural DOC. Markich et al. [27] investigated the effect of DOC (as fulvic acid) on the response of adult Hyridella depressa (Australian freshwater river mussel) to metals. They reported an 18 fold decrease in $\mathrm{Cu}$ sensitivity (as measured in terms of duration of valve opening) when the concentration of fulvic acid in the exposures was increased from 0 to $11 \mathrm{mg} / \mathrm{L}$. Hanstén et al. [28] reported that additions of 
humic acid (color value of $200 \mathrm{mg} \mathrm{Pt} / \mathrm{L}$ ) reduced the toxicity of $\mathrm{Cd}$ and $\mathrm{Cu}$ to Anodonta anatine (duck mussel) glochidia. Also with glochidia, small additions $(0.30 .6 \mathrm{mg} \mathrm{C} / \mathrm{L})$ of a standard humic substance (Aldrich humic acid) resulted in significant decreases in $\mathrm{Cu}$ toxicity of Epioblasma triquetra (snuffbox) and Lampsilis fasciola (wavy rayed lampmussel) glochidia [11]. However, it is still unknown how effective natural DOC from aquatic systems would be at protecting larval freshwater mus sels from acute $\mathrm{Cu}$ exposure.

Given the significant relationship between DOC and $\mathrm{Cu}$ bioavailability, along with the heightened sensitivity of fresh water mussels to $\mathrm{Cu}$, it is important to understand the influence of DOC on glochidia $\mathrm{Cu}$ sensitivity in order to assess the potential threat that $\mathrm{Cu}$ exposure could have on the recovery of imperiled freshwater mussels. The present study, therefore, examines the effect of natural DOC, both added and inherent (i.e., not added) on the $\mathrm{Cu}$ toxicity of the larvae of two species of freshwater mussels. Specifically, the influence of DOC on acute $\mathrm{Cu}$ toxicity of glochidia was examined using a reconstituted soft water and incremental additions of a natural organic matter, and also using a selection of source waters with their inherent natural organic matter (DOC varied from $515 \mathrm{mg} \mathrm{C/L}$ ). These data are discussed in relation to current water quality criteria as well as the implications for populations of freshwater mussels.

\section{MATERIALS AND METHODS}

\section{Mussel collection and laboratory care}

Gravid Lampsilis fasciola (Rafinesque 1820) and Lampsilis siliquoidea (Barnes 1823) (fatmucket) were collected from the Thames River, and the latter were also collected Cox Creek (Grand River Watershed), both in Ontario, Canada. L. fasciola, which has been designated as an endangered species in Canada by the Committee on the Status of Endangered Wildlife in Canada (COSEWIC), was collected under the Species at Risk Permit Number SECT 06 SCI 007. The mussels were main tained in the Aqualab facility at the University of Guelph, (Guelph, ON, Canada) in a flow through system using well water at $10 \pm 2{ }^{\circ} \mathrm{C}$ to prevent the release of glochidia. The mussels were fed a commercial shellfish diet (Instant Algae Shellfish Diet $1800^{\circledR}$ ) which is a mixture of a Nannochloropsis, Isochrysis, Pavlova, Thalassiosira, and Tetraselmis algae at a rate of approximately $1.2 \times 10^{10}$ algae cells per mussel per day.

Glochidia were collected by flushing the marsupia (brooding chambers) with water using a syringe. The viability of each mussel's glochidia was assessed prior to use (viability proce dure described below). For each exposure, glochidia were collected from a minimum of three gravid females that exhib ited greater than $90 \%$ viability. Prior to initiating an exposure, the pooled glochidia sample was gradually (over a $2 \mathrm{~h}$ period) brought up to the exposure temperature of $21^{\circ} \mathrm{C}$ by dilutions with room temperature reconstituted water.

\section{Acute copper toxicity tests with glochidia}

Toxicity tests were modeled after the American Society for Testing and Materials method [29] for conducting toxicity tests with the early life stages of freshwater mussels. Briefly, glo chidia were removed from gravid female mussels and exposed to various concentrations of a waterborne contaminant. After a given period of exposure $(24 \mathrm{~h})$, the viability of the exposed glochidia (i.e., ability to close their valves and clamp down on a fish's gill for encystment) was assessed using a concentrated salt solution $(\mathrm{NaCl} 240 \mathrm{~g} / \mathrm{L})$. Glochidia viability was assessed in a subsample (100 to 200) of the approximately 1,000 glochidia exposed in each replicate. Viability was calculated using the following equation: Percent Viability $=100 \times($ Number of closed glochidia after addition of $\mathrm{NaCl}$ - Number of closed glochidia before addition of $\mathrm{NaCl}$ ) / (Number of closed glo chidia after addition of $\mathrm{NaCl}+$ Number of open glochidia after addition of $\mathrm{NaCl}$ ). Results are expressed as EC50 values rather than median lethal concentration (LC50) values, but because they are obligatory parasites on fish, for practical purposes nonviable glochidia should be considered dead, because they would be unable to attach to a fish host and complete their life cycle.

An aqueous $\mathrm{Cu}$ stock solution made from certified American Chemical Society grade (Fisher Scientific) cupric sulfate $\left(\mathrm{CuSO}_{4} .5 \mathrm{H}_{2} \mathrm{O}\right)$ was used to create the copper exposures. Copper spiked DOC exposure solutions (described below) were accli mated to the test temperature $\left(21^{\circ} \mathrm{C}\right)$ before addition of glochi dia. Exposures ( $100 \mathrm{ml}$ per replicate) were conducted in $250 \mathrm{ml}$ glass beakers, under a 16:8 h light:dark cycle in an environ mental chamber maintained at $21 \pm 2^{\circ} \mathrm{C}$. As per the American Society for Testing and Materials method, exposure solutions were not renewed nor were the glochidia fed during the exposure. A composite water sample $(10 \mathrm{ml})$ was collected from each treatment at the beginning of the exposure for determination of dissolved (i.e., filtered through an Acrodisk ${ }^{\mathrm{TM}}$ $0.45 \mu \mathrm{m}$ in line syringe tip filter; PALL Life Sciences) $\mathrm{Cu}$ concentrations in the exposures. Water hardness, $\mathrm{pH}$, dissolved oxygen, major ions ( $\mathrm{Ca}, \mathrm{Mg}, \mathrm{Na}, \mathrm{K}, \mathrm{SO}_{4}, \mathrm{Cl}$ ), and alkalinity were also measured in water samples collected at the beginning each toxicity test. All glassware was washed with $10 \%$ nitric acid (Reagent Grade, Fisher Scientific) prior to use and all solutions were made with Millipore ${ }^{\mathrm{TM}}$ water.

\section{Effect of added DOC on copper toxicity}

Exposures with L. siliquoidea glochidia. The effect of DOC on the sensitivity of glochidia to $\mathrm{Cu}$ was assessed by conducting a series of exposures using reconstituted water and additions of concentrated natural organic matter. Dissolved natural organic matter was collected from Luther Marsh, near Guelph (ON, Canada) $\left(43^{\circ} 57^{\prime} \mathrm{N}, 80^{\circ} 26^{\prime} \mathrm{W}\right)$. One hundred liters of marsh water (raw $\mathrm{DOC}=78 \mathrm{mg} \mathrm{C} / \mathrm{L}$ ) was concentrated using a stain less steel portable reverse osmosis unit (Limnological Research) to produce a DOC concentrate of $747 \mathrm{mg} \mathrm{C} / \mathrm{L}$. In order to displace metals from the binding sites on the DOC and remove them from solution, the concentrate was treated with an $\mathrm{H}^{+}$cation exchange resin (Amberlite, IR 118H) to a $\mathrm{pH}$ of 2.3. The concentrate was stored in the dark, at $4^{\circ} \mathrm{C}$ until it was used in the $\mathrm{Cu}$ toxicity tests, at which time the $\mathrm{pH}$ was adjusted to 7.0 using sodium hydroxide (Sigma, Canada).

Individual toxicity tests, referred to as exposures, were conducted at each of $0,0.5,1.0,2.5,3.75,5.0$, and $7.5 \mathrm{mg}$ DOC/L (nominal) using the concentrated Luther Marsh DOC. Six $\mathrm{Cu}$ concentrations (treatments) were assessed in each exposure. Test solutions (water containing DOC and $\mathrm{Cu}$ ) were created by adding the desired amount of DOC concentrate to $3 \mathrm{~L}$ of reconstituted soft water [30]. Then, to each of six $0.5 \mathrm{~L}$ aliquots of the DOC water the desired amount of $\mathrm{Cu}$ stock solution was added to create a range of $\mathrm{Cu}$ concentrations (nominal 0 to $200 \mu \mathrm{g} \mathrm{Cu} / \mathrm{L}$ ). The $\mathrm{Cu}$ spiked test solutions were held in the dark at $4^{\circ} \mathrm{C}$ for $48 \mathrm{~h}$ before initiation of the exposures to allow the $\mathrm{Cu}$ DOC mixture to equilibrate [31]. Acute toxicity tests were conducted as outlined above.

Single exposure with $\mathrm{L}$. fasciola glochidia. To confirm the relationship between DOC concentration and the sensitivity of glochidia to $\mathrm{Cu}$, we examined the effect of DOC on $\mathrm{Cu}$ toxicity 
in a second, closely related mussel species, L. fasciola. Rather than conducting a series of separate exposures as was done with L. siliquoidea, a single exposure was conducted at a fixed, acutely toxic level of $\mathrm{Cu}$ while the concentration of DOC (i.e., treatments) was varied. A Cu exposure of $18 \mu \mathrm{g} / \mathrm{L}$ was chosen based on a $24 \mathrm{~h} \mathrm{EC50}$ of $17.6 \mu \mathrm{g} \mathrm{Cu} / \mathrm{L}$ (95\% confidence interval [CI] 14.2 22.6) reported by Gillis et al. [11] for this species. Test solutions were created by first adding $18 \mu \mathrm{g} \mathrm{Cu} / \mathrm{L}$ (nom inal) to $4 \mathrm{~L}$ of reconstituted soft water. Then, to each of seven $0.5 \mathrm{~L}$ aliquots of the $\mathrm{Cu}$ solution, the desired amount of DOC (nominal $07.5 \mathrm{mgC} / \mathrm{L}$ ) was added to create the DOC treat ments. The $\mathrm{Cu}$ spiked, DOC exposure solutions were held in the dark at $4{ }^{\circ} \mathrm{C}$ for $48 \mathrm{~h}$ before initiation of the exposures. Acute toxicity tests (including water analysis) were conducted as outlined above. Although the $0 \mathrm{mg} / \mathrm{L}$ DOC exposure was the true control in this exposure it contained an acutely toxic concentration of $\mathrm{Cu}$. Therefore, in order to assess the health of L. fasciola glochidia (i.e., true control survival) an additional treatment, consisting of only soft water (no $\mathrm{Cu}$ or added DOC), was conducted alongside the exposure.

\section{Effect of inherent DOC on copper toxicity}

Water was collected from eight locations in southern Ontario, Canada (see Table 1 for locations) using acid washed $18 \mathrm{~L}$ high density polyethylene buckets. The sites were chosen to represent a gradient of inherent dissolved organic carbon (Table 1). No attempt was made to match other water character istics (hardness, $\mathrm{pH}$, etc.) between the field sites. In streams and rivers, the water sample was collected from just below the surface in an area where the water was visibly flowing. In lakes, the water was collected from an open water area at least $10 \mathrm{~m}$ offshore. Water samples were transported to the laboratory and filtered through a $0.45 \mu \mathrm{m}$ filter (PALL Life Sciences) and then held in the dark at $4{ }^{\circ} \mathrm{C}$ until used in exposures (maximum of two weeks). Copper was added (spiked) to each of the field col lected waters to create a range of $\mathrm{Cu}$ concentrations (nominal, 0 to $200 \mu \mathrm{g} \mathrm{Cu} / \mathrm{L}$ ). The $\mathrm{Cu}$ spiked, field collected waters were held in the dark at $4{ }^{\circ} \mathrm{C}$ for $48 \mathrm{~h}$ before initiation of the exposures. Toxicity tests were conducted in each of the eight $\mathrm{Cu}$ spiked waters with $L$. siliquoidea glochidia as outlined above.

\section{Copper analysis}

The concentration of dissolved $\mathrm{Cu}$ in the test solutions were determined in a filtered (Acrodisk $0.45 \mu \mathrm{m}$ in line syringe tip filter) water sample collected at initiation $(t=0)$ of the toxicity test. Copper was analyzed using a graphite furnace atomic absorption spectrophotometer (Varian 220FS SpectraAA, Var ian Techtron). The detection limit for $\mathrm{Cu}$ was $0.02 \mu \mathrm{g} / \mathrm{L}$. Method blanks (3) and Fisher Scientific calibration standards (every 20 samples) were included in every run. A maximum of $5 \%$ difference between duplicates was accepted.

\section{DOC analysis}

The concentration of DOC was determined in water samples ( $10 \mathrm{ml}$, filtered using an Acrodisk $0.45 \mu \mathrm{m}$ in line syringe tip filter) collected at the beginning of each exposure using a Shimadzu total organic carbon analyzer (model 5050A; Mandel Scientific). The detection limit for DOC was $0.1 \mathrm{mg} \mathrm{C/L}$. The concentration of total organic carbon in each sample was calculated automatically by subtracting inorganic carbon from total carbon [24].

\section{Statistical analysis}

Percent glochidia survival is reported using means with standard errors (SE). The EC50s were determined by Probit Analysis (SPSS v. 11.0) using measured concentrations of dissolved copper $(t=0)$. The EC50s are presented with $95 \%$ CIs as EC50 (95\% CI). The EC50s were considered to be significantly different when their $95 \%$ CI did not overlap [32]. If the $95 \%$ CI of two EC50s overlapped, then the Litchfield and Wilcoxon [33] method was applied to determine if they were significantly different. Survival curves were produced using the statistical analysis component (Regression Wizard) of Sigma Plot v. 10.0. Statistical differences $(p<0.05)$ in glochidia survival between treatments in the L. fasciola exposure were determined using analysis of variance (ANOVA) followed by Tukey's test.

\section{Comparison of observed EC50 values to BLM predicted water quality criteria}

To determine if the current water quality regulations for $\mathrm{Cu}$ in North America will protect larval freshwater mussels, the

Table 1. The measured concentration ( $\mathrm{mg} \mathrm{C} / \mathrm{L}$ ) of dissolved organic carbon (DOC), and observed 24 h copper median effective concentrations (EC50) (95\% confidence intervals) in exposures used to assess the effect of DOC on copper toxicity in L. siliquoidea glochidia; including a series of exposures employing reconstituted soft water augmented with natural DOC (Luther Marsh, ON) and a series of eight natural field collected waters (no added DOC) from Ontario, Canada. Field sites (water body, site name and location presented) were selected to cover a range of inherent DOC concentrations (5 to 15 mg C/L). The predictions of the U.S. Environmental Protection Agency's copper biotic ligand model (BLM) version (2.2.3) [35] including the site specific final acute values (FAV) and criterion maximum concentrations (CMC) are given for each exposure

\begin{tabular}{|c|c|c|c|c|c|c|c|}
\hline Water body & Site name & Latitude & Longitude & $\begin{array}{c}\mathrm{DOC} \\
(\mathrm{mg} \mathrm{C} / \mathrm{L})\end{array}$ & $\begin{array}{c}\text { Observed } \\
\mathrm{Cu} \operatorname{EC50}(\mu \mathrm{g} / \mathrm{L})\end{array}$ & $\begin{array}{l}\text { BLM predicted } \\
\text { site specific } \\
\text { FAV }(\mu \mathrm{g} / \mathrm{L})\end{array}$ & $\begin{array}{c}\text { BLM predicted } \\
\text { site specific } \\
\text { CMC }(\mu g / L)\end{array}$ \\
\hline Lake Huron & Eagle Harbour & 44.18278 & 81.62917 & 5.0 & $30.9(26.536 .3)$ & 100.8 & 50.4 \\
\hline Lake Saint Clair & Pocket Bay & 42.53064 & 82.61963 & 5.7 & $26.7(20.336 .6)$ & 85.7 & 42.9 \\
\hline Cold Water River & Cold Water & 44.71250 & 79.64611 & 6.4 & $32.1(21.157 .1)$ & 135.4 & 67.7 \\
\hline Saugeen River & Hanover & 44.16056 & 81.03194 & 6.9 & $71.4(58.386 .5)$ & 208.6 & 104.3 \\
\hline Thames River & London & 42.97965 & 81.12756 & 9.4 & $90.9(77.6$ 106.7) & 211.5 & 105.8 \\
\hline Grand River & Doon Heritage (Kitchener) & 43.40472 & 80.4333 & 11.3 & $104.4(97.0111 .0)$ & 315.6 & 157.8 \\
\hline Sydenham River & Dawn Mills (Dresden) & 42.58925 & 82.12872 & 14.7 & $110.9(99.7124 .6)$ & 418.1 & 209.1 \\
\hline Thames River & Thamesford & 43.05601 & 80.99274 & 14.8 & $97.6(85.999 .1)$ & 455.9 & 227.9 \\
\hline Soft water (SW) & & & & 0.7 & $36.1(30.344 .0)$ & 5.4 & 2.7 \\
\hline $\mathrm{SW}+0.5 \mathrm{DOC}$ & & & & 1.2 & $42.1(34.053 .3)$ & 6.9 & 3.4 \\
\hline $\mathrm{SW}+1.0 \mathrm{DOC}$ & & & & 2.0 & 63.7 (54.2 78.6) & 12.5 & 6.3 \\
\hline $\mathrm{SW}+2.5 \mathrm{DOC}$ & & & & 3.3 & $106.5(85.4143 .3)$ & 32.7 & 16.4 \\
\hline $\mathrm{SW}+3.75 \mathrm{DOC}$ & & & & 4.4 & $150.2(127.3187 .0)$ & 33.8 & 16.9 \\
\hline
\end{tabular}


acute toxicity data produced in the present study were compared to Canadian Water Quality Guidelines (CWQG) and U.S. Ambient Water Quality Criteria (U.S. AWQC). Current CWQG are based on hardness of the receiving or testing water [34], whereas U.S. AWQC for $\mathrm{Cu}$ are derived using the U.S. EPA Cu biotic ligand model (BLM) [35] and a number of input param eters including temperature, $\mathrm{pH}, \mathrm{DOC}$, and major ion concen trations. The online version (2.2.3) of the BLM was used to derive exposure specific water quality criteria. The measured values for temperature, $\mathrm{pH}, \mathrm{DOC}, \mathrm{Ca}, \mathrm{Mg}, \mathrm{Na}, \mathrm{K}, \mathrm{SO}_{4}, \mathrm{Cl}$, and alkalinity from the exposures (see Table 2) were entered into the BLM program. The BLM output includes a final acute value (FAV) and a criterion maximum concentration (CMC) for each exposure; the BLM derived values were then compared to the observed $24 \mathrm{~h} \mathrm{Cu}$ EC50 values determined in this study.

\section{Summary of water quality and mussel distribution data}

Raw water quality data collected by the Provincial Water Quality Monitoring Network (PWQMN) were provided by the Ontario Ministry of the Environment (http://www.ene. gov.on.ca/en/publications/dataproducts). Copper $(\mu \mathrm{g} / \mathrm{L})$ and DOC $(\mathrm{mg} \mathrm{C} / \mathrm{L})$ data were provided for water samples taken between 1998 and 2008 covering a total of 134 sites across 10 Ontario conservation authorities (CAs). These $10 \mathrm{CAs}$, in particular the streams and rivers that flow through them, were selected after consultation with the chair of the Ontario Fresh water Mussel Recovery Team, (T.J. Morris, Canadian Depart ment of Fisheries and Oceans, unpublished data) because they were considered to be significant mussel habitats. The con servation authorities selected for this summary along with their main mussel habitat (i.e., river) included: Ausable Bayfield CA (Ausable River), Grand River CA (Grand River), St. Clair Region CA (Sydenham River), Long Point Region CA (Lyn River), Maitland Valley CA (Maitland River), Quinte CA (Moira and Salmon Rivers), Saugeen Valley CA (Saugeen River), Niagara Peninsula CA (Welland River), and the Upper Thames River CA and Lower Thames Valley CA (Thames River) (Fig. 1). For the purposes of this summary, the water quality and mussel distribution data from the Upper and Lower Thames CAs were combined.

Individual data points (i.e., measured concentrations for either $\mathrm{Cu}$ or DOC) were averaged over time for each PWQMN site. For each site, an average 67 individual data points (i.e., chemical analysis conducted on a specific date) were used to calculate the "site average" for $\mathrm{Cu}$ and on average 17 indi vidual data points were used to calculate the site average for DOC. Note that PWQMN did not initiate routine DOC analysis until 2001 or later and that DOC measurements were not taken at all locations (thus the lower number of DOC readings per site compared to $\mathrm{Cu}$ ). These site averages were then averaged to determine an overall mean for each CA referred herein to as a CA mean. Site averages, rather than individual readings, were used to calculate each CA mean to prevent skewing of the CA mean due to differences in sampling frequency or extreme readings (e.g., unusually high concentrations). The CA range illustrates the lowest and highest individual measured values across the entire CA over the 10 years surveyed. Because the PWQMN copper detection limit was $0.8 \mu \mathrm{g} / \mathrm{L}$, any readings below this level were set to $0 \mu \mathrm{g} / \mathrm{L}$ for purposes of calculating CA means.

Mussel distribution data were obtained from various sources ranging from individual watershed recovery plans to peer reviewed literature (Table 3). The total number of living mussel species found in each $\mathrm{CA}$ is, to the best of our knowledge, the most up to date assessment of mussel distribution in that CA using post 1996 [36] live animal survey data rather than the total number of species that have ever been found in that watershed (i.e., historic data). The number of endangered mussel species reported for each CA was obtained from a series of Department of Fisheries and Oceans (DFO) maps, which present the distribution of aquatic species at risk (fish and mussels) in each CA in Ontario (http://conservation ontar io.on.ca/projects/DFO.html).

\section{RESULTS}

\section{Effect of added DOC on copper toxicity}

L. siliquoidea exposures. The measured concentrations of DOC in the series of $L$. siliquoidea exposures were $0.7,1.2,2.0$, $3.3,4.4,5.2$, and $8.7 \mathrm{mg} \mathrm{C} / \mathrm{L}$. Control survival (24h) was $>80 \%$ in all exposures except in the two highest exposures (5.2 and $8.7 \mathrm{mg} \mathrm{C} / \mathrm{L}$ ), where it was slightly reduced (76 and $78 \%$, respectively). Additions of natural organic matter (Luther Marsh) DOC significantly reduced the toxicity of $\mathrm{Cu}$ to L. siliquoidea glochidia (Fig. 2). In the control exposure without any added DOC (0.7 $\mathrm{mg} \mathrm{C} / \mathrm{L})$, the $24 \mathrm{~h}$ EC50 was 36.1 (30.3 44.0) $\mu \mathrm{g} \mathrm{Cu} / \mathrm{L}$ (Table 1). In comparison, the $4.4 \mathrm{mg} \mathrm{C} / \mathrm{L}$ expo sure produced an EC50 of 150.2 (127.3 187.0) $\mu \mathrm{g} \mathrm{Cu} / \mathrm{L}$ and no EC50 could be determined at the two highest DOC

Table 2. Summary of measured water chemistry including pH, dissolved organic carbon (DOC) (mg/L), and concentrations (mol/L) of calcium, magnesium, sodium, potassium, sulfate, chloride, and dissolved inorganic carbon (DIC) used to predict exposure specific water quality criteria using the online version (2.2.3) of the U.S. Environmental Protection Agency's copper biotic ligand model (BLM) [35] ${ }^{\mathrm{a}}$

\begin{tabular}{|c|c|c|c|c|c|c|c|c|c|}
\hline Site label & $\mathrm{pH}$ & DOC (mg/L) & $\mathrm{Ca}(\mathrm{mol} / \mathrm{L})$ & $\mathrm{Mg}(\mathrm{mol} / \mathrm{L})$ & $\mathrm{Na}(\mathrm{mol} / \mathrm{L})$ & $\mathrm{K}(\mathrm{mol} / \mathrm{L})$ & $\mathrm{SO}_{4}(\mathrm{~mol} / \mathrm{L})$ & $\mathrm{Cl}(\mathrm{mol} / \mathrm{L})$ & $\mathrm{DIC}(\mathrm{mol} / \mathrm{L})$ \\
\hline Soft water & 7.45 & 0.7 & $2.01 \mathrm{E} 04$ & $3.04 \mathrm{E} 04$ & $6.96 \mathrm{E} 04$ & $3.58 \mathrm{E} 05$ & $5.22 \mathrm{E} 04$ & $3.22 \mathrm{E} 05$ & $6.89 \mathrm{E} 04$ \\
\hline Soft water $+0.5 \mathrm{DOC}$ & 7.23 & 1.2 & $2.12 \mathrm{E} 04$ & $3.18 \mathrm{E} 04$ & $7.48 \mathrm{E} 04$ & $3.73 \mathrm{E} 05$ & $5.47 \mathrm{E} 04$ & $3.44 \mathrm{E} 05$ & 7.69E 04 \\
\hline Soft water $+1.0 \mathrm{DOC}$ & 7.29 & 2.0 & $2.25 \mathrm{E} 04$ & $3.21 \mathrm{E} 04$ & 7.83E 04 & 2.92E 05 & $5.42 \mathrm{E} 04$ & $3.27 \mathrm{E} 05$ & 7.57E 04 \\
\hline Soft water +2.5 DOC & 7.62 & 3.3 & 2.29E 04 & $3.60 \mathrm{E} 04$ & $8.92 \mathrm{E} 04$ & 4.09E 05 & $6.30 \mathrm{E} 04$ & $3.86 \mathrm{E} 05$ & $8.41 \mathrm{E} 04$ \\
\hline Soft water +3.75 DOC & 7.43 & 4.4 & 2.04E 04 & $3.13 \mathrm{E} 04$ & $8.05 \mathrm{E} 04$ & $3.48 \mathrm{E} 05$ & $5.43 \mathrm{E} 04$ & $4.01 \mathrm{E} 05$ & 7.78E 04 \\
\hline Lake Huron & 8.30 & 5.0 & $6.51 \mathrm{E} 04$ & $3.18 \mathrm{E} 04$ & $1.80 \mathrm{E} 04$ & $2.43 \mathrm{E} 05$ & $1.71 \mathrm{E} 04$ & $1.89 \mathrm{E} 04$ & $1.68 \mathrm{E} 03$ \\
\hline Lake Saint Clair & 8.01 & 5.7 & $6.59 \mathrm{E} 04$ & $3.36 \mathrm{E} 04$ & 2.08E 04 & $2.56 \mathrm{E} 05$ & $1.76 \mathrm{E} 04$ & $2.20 \mathrm{E} 04$ & $1.42 \mathrm{E} 03$ \\
\hline Cold Water River & 8.19 & 6.4 & $1.43 \mathrm{E} 03$ & $6.50 \mathrm{E} 04$ & $5.05 \mathrm{E} 04$ & $3.89 \mathrm{E} 05$ & $1.34 \mathrm{E} 04$ & $5.27 \mathrm{E} 04$ & $3.54 \mathrm{E} 03$ \\
\hline Saugeen River & 8.54 & 6.9 & $1.28 \mathrm{E} 03$ & $1.13 \mathrm{E} 03$ & $3.43 \mathrm{E} 04$ & $2.92 \mathrm{E} 05$ & $1.72 \mathrm{E} 04$ & $3.95 \mathrm{E} 04$ & $4.06 \mathrm{E} 03$ \\
\hline Thames River (London) & 8.16 & 9.4 & $1.82 \mathrm{E} 03$ & $8.52 \mathrm{E} 04$ & $1.58 \mathrm{E} 03$ & $1.21 \mathrm{E} 04$ & $6.48 \mathrm{E} 04$ & $1.76 \mathrm{E} 03$ & $3.55 \mathrm{E} 03$ \\
\hline Grand River & 8.42 & 11.3 & $1.26 \mathrm{E} 03$ & $8.06 \mathrm{E} 04$ & $1.45 \mathrm{E} 03$ & 7.67E 05 & $3.49 \mathrm{E} 04$ & $1.61 \mathrm{E} 03$ & $3.11 \mathrm{E} 03$ \\
\hline Sydenham River & 8.47 & 14.7 & $2.02 \mathrm{E} 03$ & $5.68 \mathrm{E} 04$ & $6.52 \mathrm{E} 04$ & $1.33 \mathrm{E} 04$ & $4.66 \mathrm{E} 04$ & $9.17 \mathrm{E} 04$ & $4.31 \mathrm{E} 03$ \\
\hline Thames River (Thamesford) & 8.54 & 14.8 & $1.80 \mathrm{E} 03$ & $9.63 \mathrm{E} 04$ & $6.87 \mathrm{E} 04$ & $1.03 \mathrm{E} 04$ & $5.03 \mathrm{E} 04$ & $8.49 \mathrm{E} 04$ & 4.83E 03 \\
\hline
\end{tabular}

\footnotetext{
${ }^{\mathrm{a}}$ Temperature was $22^{\circ} \mathrm{C}$ in all exposures and the concentration of humic acid was set to $10 \%$. Field site locations are given in Table 1.
} 


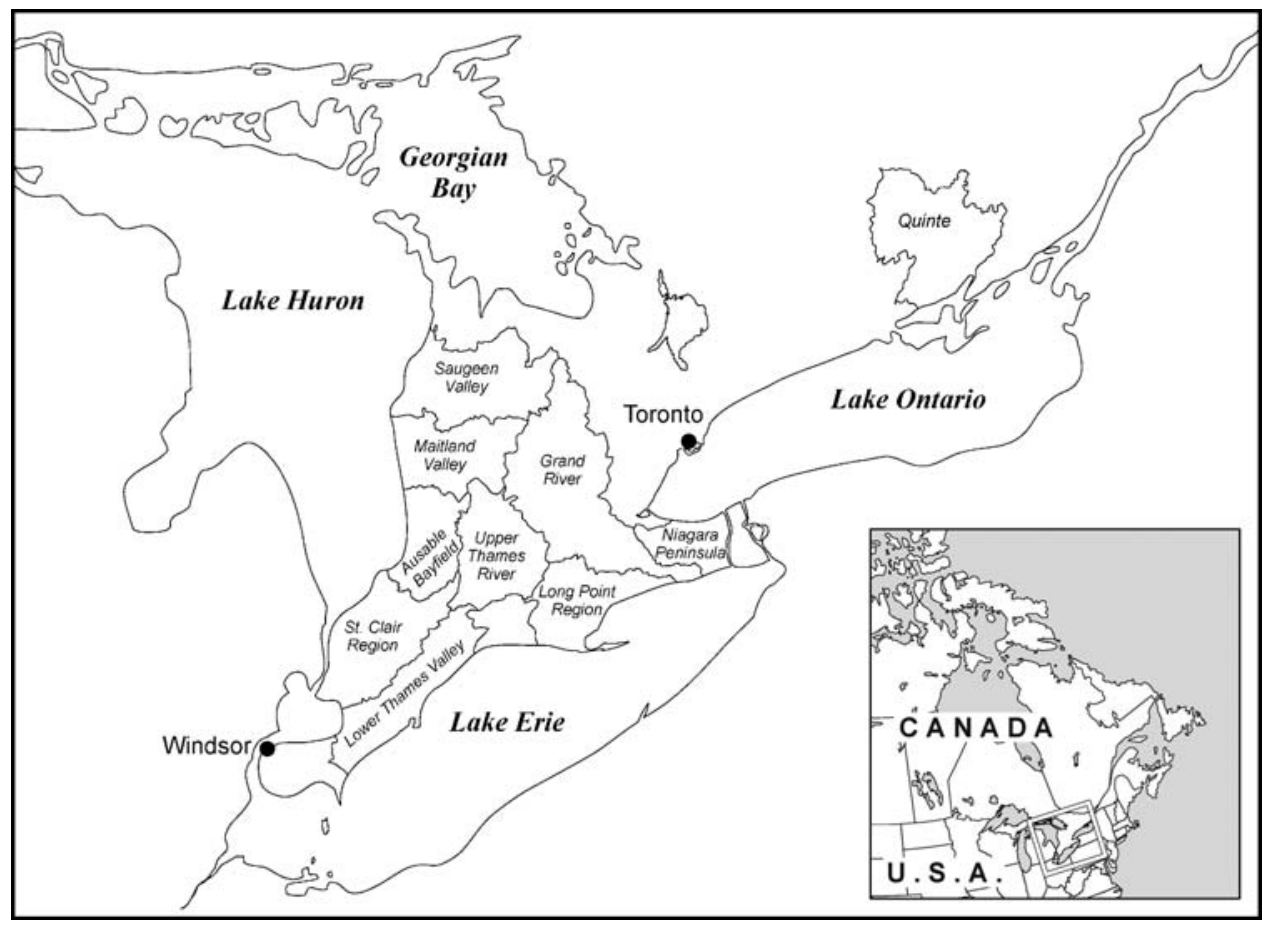

Fig. 1. Map of southern Ontario, Canada showing location of conservation authorities containing significant freshwater mussel habitats. Copper and dissolved organic carbon concentrations from these areas are summarized in Table 3.

concentrations examined because there was no significant mortality at any of the $\mathrm{Cu}$ concentrations tested. The cause of the high mortality observed in $40 \mu \mathrm{g} \mathrm{Cu} / \mathrm{L}$ treatment of the $5.2 \mathrm{mgC} / \mathrm{L}$ DOC exposure (Fig. 2F) is unknown but an error in exposure solution preparation is suspected. A sig nificant linear relationship $\left(r^{2}=0.98, p=0.0008\right)$ existed between the concentration of DOC and the resulting $\mathrm{Cu}$ EC50 (Fig. 3).
L. fasciola exposure. The $24 \mathrm{~h}$ survival of L. fasciola glo chidia in the soft water treatment without any added DOC or $\mathrm{Cu}$ was $97 \%$ ( \pm 0.7$)$. The mean measured concentration of $\mathrm{Cu}$ in the exposures was $14.9( \pm 1.3) \mu \mathrm{g} / \mathrm{L}$. The measured concentrations of DOC in the treatments were 1.5, 1.9, 2.4, 3.7, 4.7, 5.8, and $7.9 \mathrm{mg} \mathrm{C} / \mathrm{L}$. For the control copper treatment, i.e., the treatment that contained an acutely toxic amount of $\mathrm{Cu}$ but no added DOC, survival was $44.2 \%( \pm 7.7)$ after $24 \mathrm{~h}$ of exposure. A

Table 3. Summary of copper (as total copper) and dissolved organic carbon (DOC) concentrations in significant (stream and river) mussel habitats in southern Ontario and the number of mussel species found in each habitat

\begin{tabular}{|c|c|c|c|c|c|c|c|c|}
\hline \multirow{2}{*}{$\begin{array}{l}\text { Conservation authority } \\
\text { Ausable Bayfield }\end{array}$} & \multicolumn{2}{|c|}{$\begin{array}{l}\text { CA mean DOC } \\
(\mathrm{mg} \mathrm{C} / \mathrm{L})\end{array}$} & \multirow{2}{*}{$\begin{array}{c}\begin{array}{c}\text { CA range DOC } \\
(\mathrm{mg} \mathrm{C} / \mathrm{L})\end{array} \\
2.313 .7\end{array}$} & \multicolumn{2}{|c|}{$\underset{(\mu \mathrm{g} / \mathrm{L})}{\text { CA mean copper }}$} & \multirow{2}{*}{$\begin{array}{c}\begin{array}{c}\text { CA range copper } \\
(\mu \mathrm{g} / \mathrm{L})\end{array} \\
09.6\end{array}$} & \multirow{2}{*}{$\begin{array}{c}\begin{array}{c}\text { Total no. mussel } \\
\text { species [reference] }\end{array} \\
23^{\mathrm{d}}\end{array}$} & \multirow{2}{*}{$\frac{\begin{array}{l}\text { No. endangered } \\
\text { mussel species }\end{array}}{6^{\mathrm{e}}}$} \\
\hline & $5.8(1.98), n$ & 3 & & $2.02(0.67), n$ & 7 & & & \\
\hline St. Clair Region & $6.7(2.78), n$ & 3 & 1.911 .4 & $2.42(1.22), n$ & 9 & $\begin{array}{lll}0 & 12.8\end{array}$ & $34[41]$ & 11 \\
\hline Long Point Region & $3.6\left(\mathrm{NA}^{\mathrm{f}}\right), n$ & 1 & 2.010 .4 & 1.27 (NA), $n$ & 1 & 03.2 & $10^{\mathrm{g}}$ & 5 \\
\hline Maitland Valley & $5.6(0.56), n$ & 5 & 3.312 .1 & $1.52(0.42), n$ & 13 & 033.6 & $9^{\mathrm{h}}$ & 2 \\
\hline Quinte & NA & & NA & $0.97(0.46), n$ & 17 & 035.7 & $10[36]$ & 2 \\
\hline Niagara Peninsula & NA & & NA & $2.13(1.18), n$ & 3 & 08.6 & $10^{\mathrm{i}}$ & 8 \\
\hline
\end{tabular}

Water quality data (Cu and DOC) was provided by the Provincial Water Quality Monitoring Network (PWQMN) of the Ontario Ministry of the Environment ([39]; http://www.ene.gov.on.ca/en/publications/dataproducts). Mean water quality values and ranges (minimum maximum) are given for data collected from 1998 to 2008. Values reported as mean are the average of all site averages (repeated sampling at one site over time) for each conservation authority (CA). The number of individual site averages used to determine each CA mean or CA range is reported as $n$, standard deviation is given in parentheses. Mussel distribution data are from various sources (see below).

${ }^{\mathrm{a}}$ PWQMN did not initiate routine DOC analysis until 2001 or later, and DOC measurements were not taken at all locations.

${ }^{\mathrm{b}}$ The PWQMN copper detection limit was $0.8 \mu \mathrm{g} / \mathrm{L}$, therefore any copper concentration below this level has been reported as $0 \mu \mathrm{g} / \mathrm{L}$.

${ }^{\mathrm{c}}$ Designated as such by the Committee on the Status of Endangered Wildlife in Canada.

${ }^{\mathrm{d}}$ Ausable River Recovery Team. 2005. Recovery strategy for species at risk in the Ausable River (http://www.abca.on.ca/publications.php).

${ }^{\mathrm{e}}$ Endangered species data are from the Canadian Department of Fisheries and Oceans (http://conservation ontario.on.ca/projects/DFO.html).

${ }^{\mathrm{f}} \mathrm{NA}$ data not available.

${ }^{\mathrm{g}}$ J.L. Metcalfe Smith, S.K. Staton, Environment Canada, Burlington, ON, Canada, unpublished data.

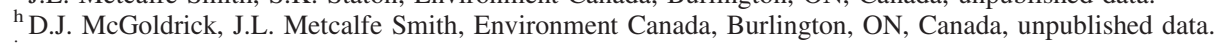

${ }^{\mathrm{i}}$ Todd Morris, Department of Fisheries and Oceans, Burlington, ON, Canada, unpublished data. 

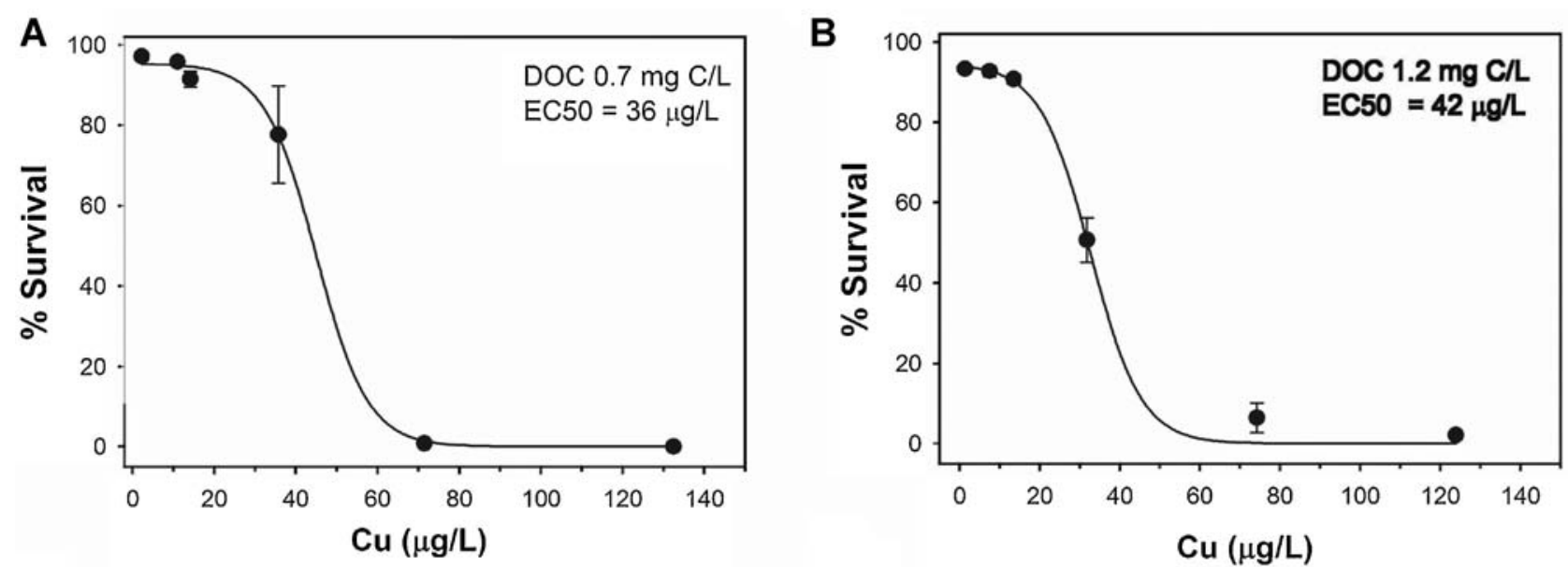

C
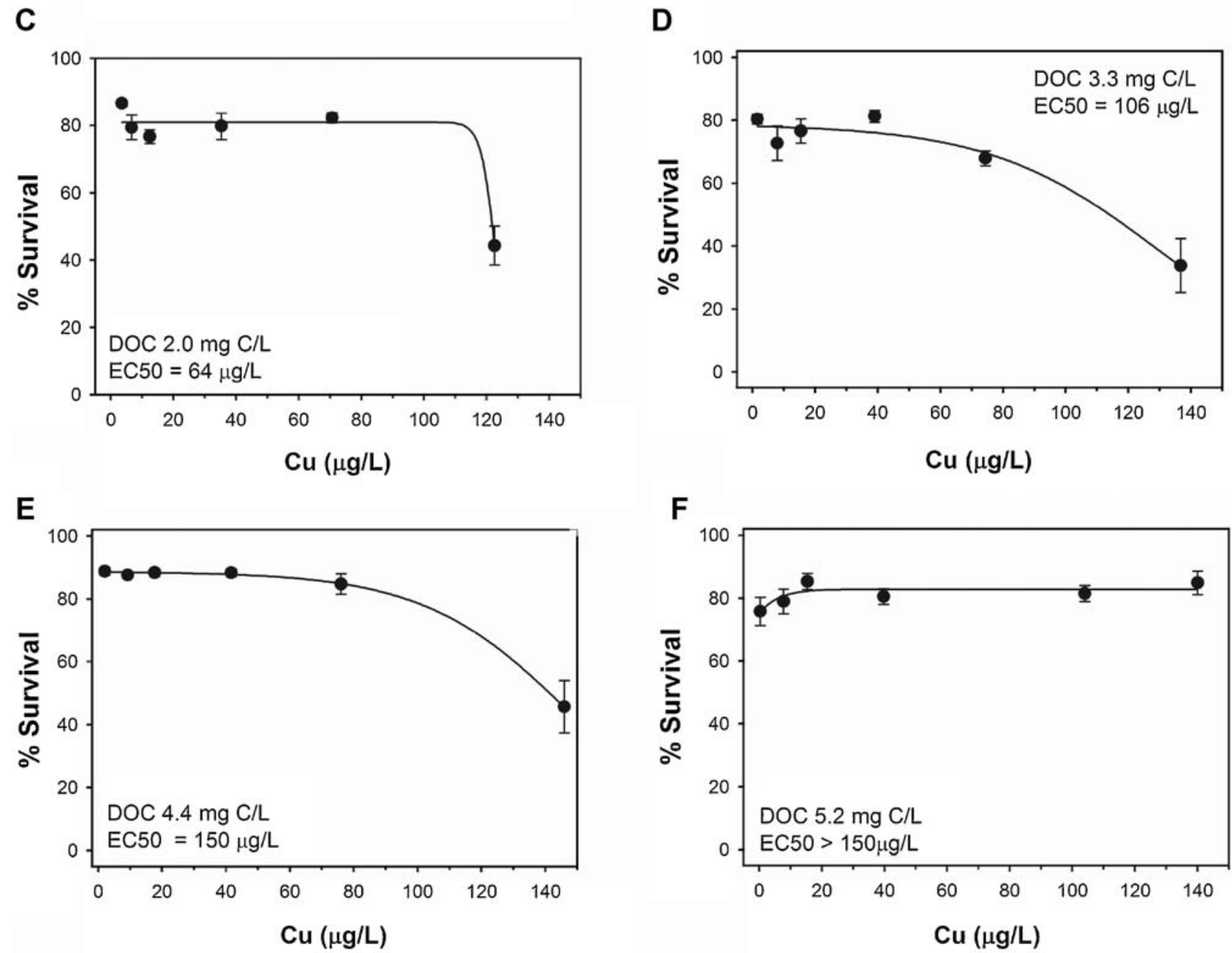

Fig. 2. Percent survival of Lampsilis siliquoidea glochidia when exposed $(24 \mathrm{~h})$ to copper in reconstituted soft water with varying amounts of added dissolved organic carbon (DOC). (A) $0.7 \mathrm{mg} \mathrm{C} / \mathrm{L},(\mathbf{B}) 1.2 \mathrm{mg} \mathrm{C/L},(\mathbf{C}) 2.0 \mathrm{mg} \mathrm{C/L},(\mathbf{D}) 3.3 \mathrm{mg} \mathrm{C/L},(\mathbf{E}) 4.4 \mathrm{mg} \mathrm{C} / \mathrm{L}$, and (F) $5.2 \mathrm{mg} \mathrm{C/L}$. Error bars represent standard errors around a mean of three replicates. EC50 median effective concentration.

significant increase in glochidia survival (compared to the control) was observed when concentrated Luther Marsh DOC was added to the $\mathrm{Cu}$ exposures. Glochidia survival in all DOC augmented treatments was more than $80 \%$, with no significant difference observed between the treatments (1.9 $7.9 \mathrm{mg} \mathrm{C} / \mathrm{L})$.

\section{Effect of inherent DOC on copper toxicity}

The concentration of naturally occurring (i.e., inherent) DOC in the field collected waters are given in Table 1. Control survival ranged from 86 to $95 \%$ in the eight field collected waters. The concentration of DOC had a significant effect on the sensitivity of $L$. siliquoidea glochidia to waterborne $\mathrm{Cu}$ expo sure (Fig. 4). The $24 \mathrm{~h} \mathrm{EC50}$ values ranged from $30.9 \mu \mathrm{g} \mathrm{Cu} / \mathrm{L}$ in water collected from Lake Huron (DOC, $5.0 \mathrm{mg} \mathrm{C} / \mathrm{L}$ ) to $110.9 \mu \mathrm{g} \mathrm{Cu} / \mathrm{L}$ in water collected from the Sydenham River (DOC, $14.7 \mathrm{mg} \mathrm{C/L}$ ). Regression analysis revealed a significant relationship $\left(r^{2}=0.79, p=0.0031\right)$ between the concentration of inherent DOC and the resulting Cu EC50 (Fig. 4). 


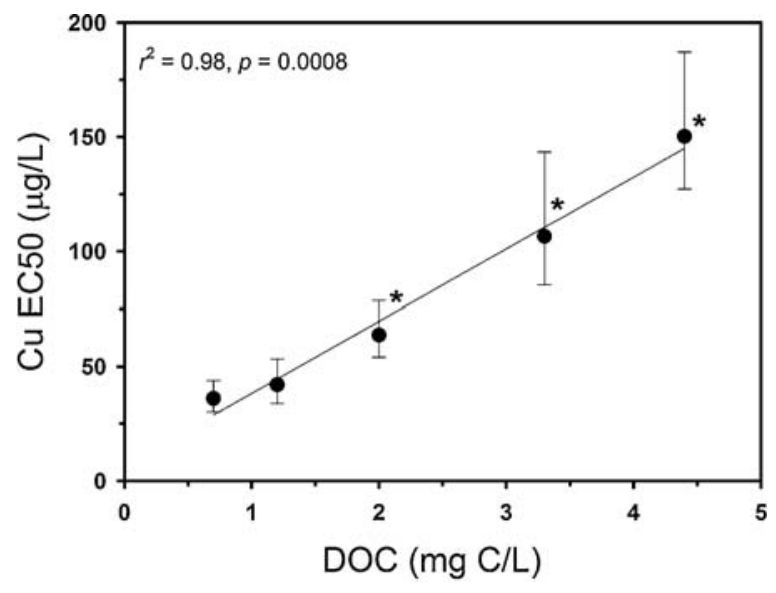

Fig. 3. The relationship between the concentration of dissolved organic carbon (DOC) and the resulting copper median effective concentration (EC50) of Lampsilis siliquoidea glochidia. Each point represents a copper 24 h median effective concentration (EC50) with 95\% confidence intervals as error bars. Each EC50 was derived from a toxicity test comprised of six copper treatments, each with three replicates. EC50s indicated with an asterisk are significantly elevated above the control EC50 (no DOC added).

\section{DISCUSSION}

\section{Effect of added DOC on copper toxicity}

The significant linear relationship between the concentration of DOC (as Luther Marsh DOC) in the exposure water and the resulting $\mathrm{Cu}$ EC50 illustrates the significant ameliorating effect that natural DOC has on $\mathrm{Cu}$ toxicity in glochidia. An increase in the concentration of DOC from $0.7 \mathrm{mg} / \mathrm{L}$ to $4.4 \mathrm{mg} / \mathrm{L}$ resulted in a fourfold increase $(36150 \mu \mathrm{g} \mathrm{Cu} / \mathrm{L})$ in the EC50 of L. siliquoidea glochidia. Similarly, a significant increase in the survival of L. fasciola glochidia was observed when natural DOC was added to an acutely toxic $\mathrm{Cu}$ exposure. Negatively charged ligands such as DOC bind with positively charged cations such as $\mathrm{Cu}$, reducing the amount of free $\mathrm{Cu}$ in solution and thus reduce the bioavailability of $\mathrm{Cu}$ [16]. The ameliorating effect of natural DOC on $\mathrm{Cu}$ toxicity in juvenile freshwater mussels (L. siliquoidea) was recently demonstrated by Wang et al. [26]. They also reported a significant linear relationship

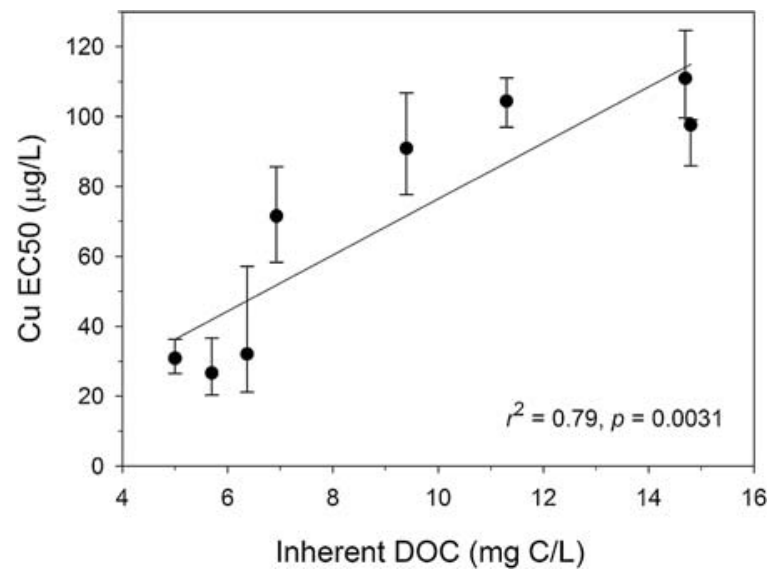

Fig. 4. The relationship between the concentration of inherent (i.e., not added) dissolved organic carbon (DOC) in various copper spiked, field collected waters (see Table 1 for site details and Table 3 for water composition) and the resulting median effective concentration (EC50) (95\% confidence intervals as error bars) for Lampsilis siliquoidea glochidia. Each point represents an EC50 derived from a toxicity test (six copper concentrations, each with three replicates) conducted in water collected from one of eight different field locations. between the concentration of DOC in an exposure and the $\mathrm{Cu}$ EC50. In one series of exposures with additions of Luther Marsh DOC and reconstituted hard water, a 4.2 fold increase in the juvenile mussel $\mathrm{Cu}$ EC50 was observed when DOC was raised from 0 to $5 \mathrm{mg} \mathrm{C} / \mathrm{L}$ [26]. This is nearly identical to the fourfold increase in the glochidia $\mathrm{Cu}$ EC50 reported in the present study when DOC was increased from $<1$ to $4.4 \mathrm{mg} \mathrm{C} / \mathrm{L}$ using Luther Marsh DOC and reconstituted soft water. Additions of DOC have also been shown to reduce $\mathrm{Cu}$ toxicity in a number of aquatic species. In cladocerans, Giesy et al. [20] reported that the presence of organic matter reduced the accumulation of $\mathrm{Cu}$ in Simocephalus serrulatus, and De Schamphelaere and Janssen [21], as well as De Schamphelaere et al. [22] demonstrated the protective effect of natural DOC additions on the copper toxicity in Daphnia magna. Similarly, in fish (rainbow trout [24]; fathead minnow [18]) acute $\mathrm{Cu}$ toxicity has been shown to decrease when the concentration of DOC in the exposure water was increased. Nadella et al. [37] also recently demonstrated the ameliorating effect of added DOC on the $\mathrm{Cu}$ sensitivity of the embryos of marine mussels (Mytilus trossolus).

\section{Effect of inherent DOC on copper toxicity}

The concentration of inherent DOC in natural waters had a significant effect on the sensitivity of glochidia to $\mathrm{Cu}$. Copper sensitivity of $L$. siliquoidea glochidia exposed to $\mathrm{Cu}$ spiked water from Lake Huron (EC50 $30.9 \mu \mathrm{g} / \mathrm{L}$ ), the field collected water with the lowest concentration of DOC (5.0 $\mathrm{mg} \mathrm{C} / \mathrm{L})$, was similar to the EC50 $(36.1 \mu \mathrm{g} \mathrm{Cu} / \mathrm{L})$ in reconstituted soft water exposures; however, when acute copper toxicity was assessed in water collected from the Grand River (DOC $11.3 \mathrm{mg} \mathrm{C} / \mathrm{L}$ ), the resulting EC50 was nearly three times higher than that of the soft water exposure (EC50 104.4 $\mu \mathrm{g} \mathrm{Cu/L).} \mathrm{A} \mathrm{significant}$ relationship between the concentration of inherent DOC and the toxicity of $\mathrm{Cu}$ was also demonstrated in the embryos of marine mussels [25]. Arnold [25] found that the Cu EC50 of Mytilus galloprovincialis was highly correlated $\left(r^{2}=0.71, p<0.001\right)$ to the concentration of inherent DOC in the water (54 natural marine waters tested).

It should be noted that dissolved organic carbon was not the only water chemistry parameter that varied across the natural waters employed in the present study; water hardness also ranged from 84 to $284 \mathrm{mg} \mathrm{CaCO}_{3} / \mathrm{L}$ (Table 2 presents water composition of the field collected waters). Interestingly, there was a positive and significant correlation (Pearson correlation coefficient $0.81, p=0.015$ ) between water hardness and the concentration of inherent DOC in the natural waters used in the present study. The bioavailability of $\mathrm{Cu}$ is known to be influ enced by a number of water chemistry parameters, including the concentrations of major cations $(\mathrm{Ca}, \mathrm{Mg}, \mathrm{Na})$ [14,15]. Water hardness has been shown to decrease $\mathrm{Cu}$ sensitivity of glochidia in exposures using reconstituted waters. For example Epio blasma triquetra glochidia exposed to $\mathrm{Cu}$ in moderately hard (166 mg $\left.\mathrm{CaCO}_{3} / \mathrm{L}\right)$ water had an EC50 twofold higher than those exposed in soft $\left(40 \mathrm{mg} \mathrm{CaCO}_{3} / \mathrm{L}\right)$ water [11]. Although the effect of water hardness is significant, increases in water hardness do not appear to affect $\mathrm{Cu}$ bioavailability as strongly as increases in DOC. Again, our earlier exposures with E. triquetra and Aldrich humic acid demonstrated that a small increase in the DOC also resulted in a doubling of the EC50 [11]. However, the presence of other toxicity modifying factors in our field collected water exposures explains the variability observed in the linear regression of DOC on EC50 for natural waters (Fig. 4) versus reconstituted waters (Fig. 2). 


\section{Comparison of added DOC and inherent DOC}

On a per concentration basis, it appears that the Luther Marsh DOC, which was added to toxicity tests using recon stituted water, was much more effective at reducing the bio availability of $\mathrm{Cu}$ than the natural DOC in the field collected waters. For example, exposures with $4.4 \mathrm{mg} \mathrm{C} / \mathrm{L}$ of Luther Marsh DOC resulted in an EC50 of $150 \mu \mathrm{g} \mathrm{Cu} / \mathrm{L}$. In compar ison, the EC50 values in $\mathrm{Cu}$ spiked natural waters with inherent DOC concentrations of 5 to $6 \mathrm{mg} \mathrm{C} / \mathrm{L}$ all had EC50 values less than $40 \mu \mathrm{g} \mathrm{Cu} / \mathrm{L}$. A number of factors may have contributed to this difference including the source of the DOC. Schwartz et al. [24] compared natural organic matter (NOM) from a number of sources with respect to their ameliorating effect on metal toxicity. They demonstrated that the NOM from Luther Marsh, an optically dark NOM which is dominated by allochthonous (terrestrially derived) material, reduced Ag toxicity in fish to a greater degree than did other optically lighter NOMs. Typically, darker colored NOMs have more metal complexing abilities than the lighter autochthonous NOMs (i.e., those derived from aquatic photosynthesis) that are found in large lakes and oceans [23,24]. In fact, Luider et al. [23] reported that darker colored NOMs had about twofold greater $\mathrm{Cu}$ binding capacity com pared to the lighter colored ones.

Although we did not isolate the natural organic matter from the field collected waters to quantify darkness (or composition) in the present study, based on earlier research it seems appro priate that the DOC from the large lakes and rivers we tested would be more autochthonous in nature (therefore less effective at binding $\mathrm{Cu}$ ) and this may explain the relatively lower protective effects compared to Luther Marsh DOC. An alter native, or perhaps confounding, reason for the observed differ ence between the ameliorating capabilities of the Luther Marsh and other field collected DOCs, may lie in the differences in the composition of the water used in the exposures. The reconsti tuted water used in the Luther Marsh exposures was much softer $\left(40 \mathrm{mg} \mathrm{CaCO}_{3} / \mathrm{L}\right)$ than the natural waters used to assess the effect of inherent DOC (84 $284 \mathrm{mg} \mathrm{CaCO}_{3} / \mathrm{L}$ ). As discussed above, glochidia have been shown to be less sensitive to $\mathrm{Cu}$ when exposed in hard water compared to soft water $[9,11]$. The increased concentration of major ions $\left(\mathrm{Ca}^{2+}, \mathrm{Mg}^{+}\right)$in hard water leads to increased competition between those ions and the copper ion $\left(\mathrm{Cu}^{2+}\right)$ for binding sites on the organism $[14,15]$. In addition to competition for binding sites on the organism, there will also be competition among the various cations $\left(\mathrm{Ca}^{2+}, \mathrm{Mg}^{+}, \mathrm{Cu}^{2+}\right)$ for binding sites on the DOC molecules. Mantoura et al. [19] reported that $\mathrm{Mg}$ and $\mathrm{Ca}$ compete with $\mathrm{Cu}$ for binding sites on the humic acid molecule. Similarly, Iglesias et al. [38] found that the degree of $\mathrm{Cu}$ complexation with fulvic acid decreased as the concentration of $\mathrm{Ca}^{2+}$ in the exposure medium increased. This would indicate that DOC would be more effective at reducing the bioavailability of $\mathrm{Cu}$ in soft water than in hard water. Therefore, we suggest that the enhanced protective ability of the Luther Marsh DOC in soft waters compared to the DOC from field collected waters is a result of both the increased metal binding capabilities of this allochth onous dominated DOC and the ion dilute soft water used in the exposures.

\section{Copper sensitivity: water quality criteria and guidelines}

Currently, Canadian Water Quality Guidelines for $\mathrm{Cu}$ are based on water hardness. For waters with hardness less than $120 \mathrm{mg} \mathrm{CaCO}_{3} / \mathrm{L}$ the guideline is $2 \mu \mathrm{g} \mathrm{Cu} / \mathrm{L}$ [34]. For waters with hardness between 120 and $180 \mathrm{mg} \mathrm{CaCO}_{3} / \mathrm{L}$, the guideline is $3 \mu \mathrm{g} \mathrm{Cu} / \mathrm{L}$ [34]. These guidelines would be protective con sidering the EC50 values derived from the natural water expo sures of the present study ranged from 27 to $111 \mu \mathrm{g} \mathrm{Cu} / \mathrm{L}$. Currently, the most scientifically advanced regulatory approach for $\mathrm{Cu}$ is the U.S. EPA Ambient Water Quality Criteria, which are derived on a site specific basis using the biotic ligand model (BLM) [35]. Table 1 presents the observed EC50 values along side the BLM predicted final acute values (FAVs) and criterion maximum concentrations (CMC) derived for the exposures in the present study. The CMC (or acute criteria) values (half the FAV) produced range between 43 and $228 \mu \mathrm{g} \mathrm{Cu} / \mathrm{L}$ (Table 2). Typically, the actual water quality criteria, the criterion con tinuous concentration (CCC or chronic criteria), which is the maximum $4 \mathrm{~d}$ mean concentration that is allowed over a three year period, is derived by applying the acute to chronic ratio to the CMC. The application of the BLM (v. 2.2.3, in Cu WQC Calculation mode) produced predicted FAV values that for every natural field collected water were greater than the meas ured toxicity (Table 1). A number of explanations are possible. For example, it is possible that the natural waters came with a contaminant load that resulted in glochidia being sensitized to $\mathrm{Cu}$. Alternatively, it is possible that DOC bound $\mathrm{Cu}$ is bioavailable to glochidia and contributes to toxicity. It is also possible that BLM predictions generally overestimate protec tive effects, particularly at elevated $\mathrm{pH}$. All of the natural waters tested had $\mathrm{pH}$ values over 8.0 (range 8.18 .6 ). In any event, the BLM was not able to predicted $\mathrm{Cu}$ toxicity to glochidia in natural waters and set FAV values that were inappropriate. Whether the anomaly between measured and BLM predicted toxicity results from unique features of the organism or the model (or both) is unknown; however, it is deserving of further study.

\section{Implications for native populations of mussels}

The rivers and streams of the lower Great Lakes Basin contain the richest assemblage of freshwater mussel species in Canada [36]. Forty species of mussels are found in this area, including 11 federally endangered species (http://conservation ontario.on.ca/projects/DFO.html). After surveying both historic (pre 1960) and more recent mussel distribution data of southern Ontario, Metcalfe Smith et al. [36] concluded that significant species losses and community changes in the freshwater mussel populations have occurred. They suggested that even by con servative estimates, somewhere between one sixth and one third of the mussel fauna in the Grand, Thames, and Sydenham Rivers have been lost. Although the decline of native mussels in North America has been attributed to a number of factors, including habitat alternation, loss of fish hosts, and the invasive zebra mussel, environmental pollution is also considered to have contributed to the decline of native freshwater mussels. However, until recently research in this area has been somewhat limited and thus the impact of waterborne contaminants on native mussel populations is still uncertain. In fact, all of the recovery strategies for freshwater mussel produced to date in Canada have indicated the "urgent need" to examine the threat that waterborne contaminants pose to the recovery of imperiled freshwater mussels. Therefore, to address this need, we exam ined the results of this laboratory based toxicity study in the context of the measured levels of $\mathrm{Cu}$ in the mussel's natural habitat.

A summary of the copper (as total $\mathrm{Cu}$ ) and DOC concen trations found in significant (stream and river) mussel habitats in Ontario over the past 10 years is presented in Table 3. Data were compiled by conservation authority. The number of 
mussel species found within each conservation authority area, as well as the number of endangered species, are also included. According to PWQMN data, the concentration of $\mathrm{Cu}$ found in mussel habitats in southern Ontario has ranged from less than detectable $(<0.8 \mu \mathrm{g} / \mathrm{L})$ to $54.3 \mu \mathrm{g} / \mathrm{L}$ over the past 10 years, and the mean $\mathrm{Cu}$ concentration (see Materials and Methods for explanation) across the CAs ranged from 0.6 to $2.4 \mu \mathrm{g} \mathrm{Cu} / \mathrm{L}$ (Table 3). Although the Ontario Ministry of the Environment did not initiate routine DOC analysis until 2001, and DOC measurements were not taken at all locations, the data available indicate that the concentration of inherent DOC ranged from 1.9 to $13.7 \mathrm{mg} \mathrm{C} / \mathrm{L}$ at these sites. The overall $\mathrm{CA}$ means for DOC spanned 3.6 to $6.7 \mathrm{mg} \mathrm{C/L}$ (Table 3). Therefore, according to our earlier [11] laboratory based acute toxicity tests using reconstituted soft water (no added DOC), the mean $\mathrm{Cu}$ con centration in the mussel habitats surveyed does not exceed the level found to be acutely toxic to even the most sensitive of the

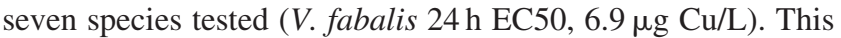
conclusion is supported by EC50 values derived from toxicity tests conducted in $\mathrm{Cu}$ spiked natural waters in the present study. For example, waters with similar levels of inherent DOC as the mean levels found in the CAs examined (4 to $7 \mathrm{mg} \mathrm{C} / \mathrm{L}$ ) produced EC50 values that ranged from 31 to $71 \mu \mathrm{g} \mathrm{Cu} / \mathrm{L}$. This is more than an order of magnitude above the mean level of $\mathrm{Cu}$ reported in the rivers examined. Even though the mean levels of DOC and $\mathrm{Cu}$ in the mussel habitats of southern Ontario indicate that exposure to acutely toxic levels of $\mathrm{Cu}$ is not the typical situation, the episodic pulses or spikes of $\mathrm{Cu}$ may be of concern, depending on the DOC concentration of the water at that time. For instance, in the Thames River, a habitat that supports 11 federally endangered species of mussels, $\mathrm{Cu}$ has been found to exceed $50 \mu \mathrm{g} / \mathrm{L}$ on occasion. With variation in DOC concentrations (for example, $2.911 .7 \mathrm{mg} \mathrm{C} / \mathrm{L}$ in the Thames River, PWQMN data) even short term spikes in $\mathrm{Cu}$ concentration could be harmful, especially if the spike occurs at a sensitive stage in the reproductive cycle, particularly during the time that glochidia are released into the water column (May October). The significant mussel habitats of southern Ontario are typically DOC rich and while there are many instances in nature in which excess nutrients and DOC can lead to a deterioration of water quality (i.e., eutrophication), the results of the present study indicate that the inherent DOC found in mussel habitats in southern Ontario should, on average, provide freshwater mussels with protection from acute $\mathrm{Cu}$ toxicity, although further study into the effects of episodic $\mathrm{Cu}$ release on endemic freshwater mussels would be beneficial.

Although the acute $\mathrm{Cu}$ sensitivity of glochidia has been assessed in a variety of mussel species $[8,10,11]$, the diversity of the exposure water used in those studies was very limited. Typically, reconstituted waters have been used to determine an organism's sensitivity to a contaminant and, although such standardized waters are useful for comparing sensitivities among species and among studies, they do not necessarily reflect the complexity of the water found in an organism's natural habitat. Because freshwater mussels are found in a wide range of habitats from small urbanized streams to large oligo trophic lakes, it is important to understand their vulnerability to contaminants under such diverse conditions. By assessing the $\mathrm{Cu}$ sensitivity of glochidia in a range of natural waters we have demonstrated that the sensitivity of glochidia to $\mathrm{Cu}$ not only depends on the species [11], but also on the composition of the water, especially the concentration of DOC, in which they live.

\section{CONCLUSION}

In conclusion, the present study has demonstrated the sig nificant protective effect that natural organic matter (as DOC) has on acute $\mathrm{Cu}$ toxicity in glochidia. The significant relation ship between the concentration of inherent DOC and copper toxicity emphasizes that an understanding of the DOC level in the mussel's natural habitat is necessary to assess the bioavail ability of $\mathrm{Cu}$ and its potential threat to the sensitive early life stages of freshwater mussels.

Acknowledgement This work was supported by the World Wildlife Fund (Endangered Species Recovery Fund (WWF Canada)), the Copper Develop ment Association, and the Species at Risk Espèces en Péril (Department of Fisheries and Oceans Canada). The authors thank R. Mitchell, K. McNichols, A. Schwalb, P. Ragaz, J. Klink, O. Birceanu, and G. Nishihara for assistance in the laboratory and field, as well as A. Todd and S. Sunderani of the Ontario Ministry of the Environment for providing the raw water quality data (PWQMN), and T. Morris (DFO) for assistance selecting mussel habitats and making mussel distribution data available to us. O. Bireanu was supported by an NSERC Metals in the Human Environment Strategic Network grant.

\section{REFERENCES}

1. U.S. Fish and Wildlife Service 1990. Endangered and threatened wildlife and plants. Fed Reg 59:58982 59028.

2. Williams JD, Warren ML, Cummings KS, Harris JL, Neves RJ. 1993. Conservation status of freshwater mussels of the United States and Canada. Fisheries 18:6 22.

3. Bogan AE. 1993. Freshwater bivalve extinctions (Mollusca: Unionidae): a search for causes. Am Zool 33:599 609.

4. Gillis PL, Mackie GL. 1994. Impact of the zebra mussel, Dreissena polymorpha, on populations of Unionidae (Bivalvia) in Lake St. Clair. Can J Zool 72:1260 1271.

5. Fleming WJ, Augspurger TP, Alderman JA. 1995. Freshwater mussel die off attributed to anticholinesterase poisoning. Environ Toxicol Chem $14: 877879$

6. Huebner JD, Pynnönen KS. 1992. Viability of two species of Anodonta exposed to low pH and selected metals. Can J Zool 70:2348 2355.

7. Cope WG, Bringolf RB, Buchwalter DB, Newton TJ, Ingersoll CG, Wang N, Augspurger T, Dwyer FJ, Barnhart MC, Neves RJ, Hammer E. 2008. Differential exposure, duration, and sensitivity of unionoidean bivalve life stages to environmental contaminants. J North Am Benthol Soc 27:451 462.

8. Jacobson PJ, Neves RJ, Cherry DS, Farris JL. 1997. Sensitivity of glochidial stages of freshwater mussels (Bivalvia: Unionidae) to copper. Environ Toxicol Chem 16:2384 2392.

9. Keller AE, Zam SG. 1991. The acute toxicity of selected metals to the freshwater mussel. Anodanta imbelilis. Environ Toxicol Chem 10:539 546.

10. Wang N, Ingersoll CG, Hardesty DK, Ivey CD, Kunz JL, May TW, Dwyer FJ, Roberts AD, Augspurger T, Kane CM, Neves RJ, Barnhart MC. 2007. Acute toxicity of copper, ammonia, and chlorine to glochidia and juvenile mussels. Environ Toxicol Chem 26:2036 2047.

11. Gillis PL, Mitchell RJ, Schwalb AN, McNichols KA, Mackie GL, Wood CM, Ackerman JD. 2008. Sensitivity of the glochidia (larvae) of freshwater mussels to copper: Assessing the effect of water hardness and dissolved organic carbon on the sensitivity of endangered species. Aquat Toxicol 88:137 145.

12. March FA, Dwyer FJ, Augspurger T, Ingersoll CG, Wang N, Mebane CA. 2007. An evaluation of water quality guidance and standards for copper. Environ Toxicol Chem 26:2066 2074.

13. Ward S, Augspurger T, Dwyer FJ, Kane C, Ingersoll CG. 2007. Risk assessment of water quality in three North Carolina streams supporting federally endangered freshwater mussels. Environ Toxicol Chem 26:2075 2085.

14. Pagenkopf GK. 1983. Gill surface interaction model for trace metal toxicity to fishes: Role of complexation, pH, and water hardness. Environ Sci Technol 17:342 347.

15. Playle RC. 1998. Modelling metal interactions at fish gills. Sci Total Environ 219:147 163.

16. Playle RC, Dixon DG, Burnison K. 1993. Copper and cadmium binding to fish gills: Modification by dissolved organic carbon and synthetic ligands. Can J Fish Aquat Sci 50:2667 2677.

17. Campbell PGC. 1995. Interactions between trace metals and aquatic organisms: A critique of the free ion activity model. In Tessier A, Turner 
DR, eds Metal Speciation and Bioavailability in Aquatic Systems. John Wiley, New York, NY, USA, pp 45102.

18. Santore RC, Di Toro DM, Paquin PR, Allen HE, Meyer JS. 2001. A biotic ligand model of the acute toxicity of metals: II: Application to acute copper toxicity in freshwater fish and Daphnia. Environ Toxicol Chem 20:2397 2402.

19. Mantoura RFC, Dickson A, Riley JP. 1978. The complexation of metals with humic materials in natural waters. Estuar Coast Mar Sci 6:386 408.

20. Giesy JP, Newell A, Leversee GL. 1983. Copper speciation in soft, acid, humic waters: effects on copper bioaccumulation by and toxicity to Simocephalus serrulatus (Daphnidae). Sci Total Environ 28:23 36.

21. De Schamphlelaere KAC, Janssen CR. 2004. Effects of dissolved organic carbon concentration and source, $\mathrm{pH}$, and water hardness on chronic toxicity of copper to Daphnia magna. Environ Toxicol Chem 23:115 1122

22. De Schamphelaere KAC, Vasconcelos FM, Tack FMG, Allen HE Janssen CR. 2004. The effect of dissolved organic matter source on acute copper toxicity of Daphnia magna. Environ Toxicol Chem 23:1248 1255.

23. Luider CD, Crusius J, Playle RC, Curtis PJ. 2004. Influence of natural organic matter source on copper speciation as demonstrated by $\mathrm{Cu}$ binding to fish gills, by ion selective electrode, and by DGT gel sampler. Environ Sci Technol 38:2865 2872.

24. Schwartz ML, Curtis PJ, Playle RC. 2004. Influence of natural organic matter source on acute copper, lead, and cadmium toxicity to rainbow trout (Oncorhynchus mykiss). Environ Toxicol Chem 23:2889 2899.

25. Arnold WR. 2005. Effects of dissolved organic carbon on copper toxicity: Implications for saltwater copper criteria. Integr Environ Assess Manag 1:34 39.

26. Wang N, Mebane CA, Kunz JL, Ingersoll CG, May TW, Arnold WR, Santore RC, Augspurger T, Dwyer FJ, Barnhart MC. 2009. Evaluation of acute copper toxicity to juvenile freshwater mussels (fatmucket, Lampsilis siliquoidea) in natural and reconstituted waters. Environ Toxicol Chem 28:2367 2377.

27. Markich SJ, Brown PL, Jeffree RA, Lim RP. 2003. The effects of dissolved organic carbon on the toxicity of cadmium and copper to a freshwater bivalve: further support for the extended free ion activity model. Arch Environ Contam Toxicol 45:479 491.

28. Hanstén C, Heino M, Pynnönen K. 1996. Viability of glochidia of Anodanta anatine (Unionidae) exposed to selected metals and chelating agents. Aquat Toxicol 34:1 12.

29. American Society for Testing and Materials. 2006. Standard guide for conducting laboratory toxicity tests with freshwater mussels. E2455 06. In Annual Book of ASTM Standards, Vol 11.06. West Conshohocken, PA, pp 13931444
30. American Society for Testing and Materials. 2006. Standard guide for conducting acute toxicity tests on test materials with fishes, macro invertebrates and amphibians. E 729 96. In Annual Book of ASTM Standards, Vol 11.06. West Conshohocken, PA, pp 79100

31. Ma H, Kim SD, Cha DK, Allen HE. 1999. Effect of kinetics of complexation by humic acid on toxicity of copper to Ceriodaphnia dubia. Environ Toxicol Chem 18:828 837.

32. Environment Canada. 2005. Guidance document on statistical methods for environmental toxicity tests. EPS 1/RM/46. Method Development and Applications Section, Environmental Technology Centre, Environ ment Canada, Ottawa, ON.

33. Litchfield JT, Wilcoxon F., 1949. A simplified method of evaluating dose effective experiments. J Pharmacol Exp Ther 96:99 113.

34. Canadian Council of Ministers of the Environment. 2005. Canadian water quality guidelines. Environment Canada, Ottawa, ON.

35. U.S., Environmental Protection Agency. 2007. Aquatic life ambient freshwater quality criteria Copper. EPA 822 R 07001 . Office of Water Washington, DC.

36. Metcalfe Smith JL, Staton SK, Mackie GL, Lane NM. 1998. Changes in the biodiversity of freshwater mussels in the Canadian waters of the lower Great Lakes drainage basin over the past 140 years. J Gt Lakes Res 24:845 858

37. Nadella SR, Fitzpatrick JL, Franklin N, Bucking C, Smith S, Wood CM. 2009. Toxicity of dissolved $\mathrm{Cu}, \mathrm{Zn}, \mathrm{Ni}$ and $\mathrm{Cd}$ to developing embryos of the blue mussel (Mytilus trossolus) and the protective effect of dissolved organic carbon. Comp Biochem Physiol C 149:340 348

38. Iglesias A, Lopez R, Fiol S, Antelo JM, Arce F. 2003. Analysis of copper and calcium fulvic acid complexation and competition effects. Water Res 37:3749 3755 .

39. Ontario Ministry of the Environment. 2009. Provincial Water Quality Monitoring Network (PWOMN) Database. Toronto, ON, Canada.

40. Metcalfe Smith JL, Mackie GL, Di Maio J, Staton SK. 2000. Changes over time in the diversity and distribution of freshwater mussels (Unionidae) in the Grand River, Southwestern Ontario. J Gt Lakes Res 26:445 459 .

41. Jacques Whitford Environment Limited. 2001. Sydenham River recovery project: Synthesis and analysis of background data. Project ONO50368. Ottawa, ON, Canada.

42. Morris TJ, Granados M, Edwards A. 2007. A preliminary survey of the freshwater mussels of the Saugeen River Watershed, Ontario. Manu script 2809. Canadian Manuscript Report of Fisheries and Aquatic Sciences, Ottawa, ON

43. Morris TJ, Edwards A. 2007. Freshwater mussel communities of the Thames River, Ontario: 2004 2005. Manuscript 2810. Canadian Manuscript Report of Fisheries and Aquatic Sciences, Ottawa, ON. 